\title{
O ETERNO RETORNO COMO IMPERATIVO EXISTENCIAL
}

\author{
Barbara Smolniakof ${ }^{1}$
}

\begin{abstract}
RESUMO: Este artigo apresenta o eterno retorno de Friedrich Nietzsche como um imperativo existencial, isto é, um conselho que diz ao homem para viver a vida de modo tal que ele queira vivê-la infinitas vezes. Seu ponto de partida é uma tese cosmológica, uma perspectiva do mundo constituído por forças finitas que se desenvolvem dentro de um tempo infinito. Da combinação destes dois elementos surgiria o retorno eterno dos mesmos instantes já efetivados.
\end{abstract}

Palavras-chave: Eterno Retorno; Imperativo; Afirmação; Existência.

\section{ETERNAL RETURN AS EXISTENTIAL IMPERATIVE}

ABSTRACT: This article presents Friedrich Nietzsche's eternal return as an existential imperative, that is, an advice that recomends to live the life so that someone would want this. Its starting point is a cosmological thesis, a perspective of the world made up of finite forces that develop within an infinite time. The combination of these two elements would result in the eternal return from the same instants already effected.

Key words: Eternal Return; Imperative; Affirmation; Existence.

\section{INTRODUÇÃO}

Este artigo discute a doutrina do eterno retorno no pensamento de Friedrich Wilhelm Nietzsche (1844-1900). Mais precisamente, procuramos expô-la como um imperativo, que sugere a valorização da existência tal como é vivida. Esta proposta tem como ponto de partida a hipótese de um tempo cíclico, concebido sem princípio e finalidade determinados, tão somente como a suposição de que tudo retorna repetida e infinitamente. Tal noção de tempo interage com forças que são finitas e leva a uma repetição dos mesmos instantes efetivados ao invés de a estados novos. Esta perspectiva vai de encontro à tradição metafísico-teleológica, ${ }^{2}$ que concebe um tempo linear com um télos determinado. Em seguida, apresentamos sua proposta de uma nova forma de

\footnotetext{
1 Graduada em Filosofia pela Universidade Estadual do Centro-Oeste do Paraná (UNICENTRO). Mestranda em Filosofia pela Universidade Federal de Santa Catarina (UFSC). E-mail: barbarasmolniakof@gmail.com

${ }^{2}$ Ver nesse sentido MARTON, S. A Morte de Deus e a Transvaloração dos valores. In: HYPNOS, São Paulo, ano $4, n^{\circ} 5,2^{\circ}$ semestre, 1999, p. 134. Neste artigo a comentadora põe em questão a relação pensada por Nietzsche entre homem e mundo, bem como a noção de valor e de vida e a característica fundamental da filosofia nietzschiana, isto é, a crítica como pano de fundo da declaração da morte de Deus e do advento do niilismo.
} 
valorização da vida a partir desta nova temporalidade, concebida como a repetição do instante.

Podemos dizer que, para Nietzsche, a tradição metafísica começa em Platão, dado que com ele se estabelece um novo horizonte para a filosofia. Entre os pré-socráticos, a filosofia era uma forma de pensamento muito ligada ao mundo que a rodeava. Os filósofos pré-socráticos, também denominados físicos, buscavam a origem de todas as coisas em princípios naturais como a água (como fizera Tales de Mileto), o movimento e a transformação constante das coisas (Heráclito de Éfeso) ou o ar (Anaxímenes de Mileto). Já com a passagem da tradição pré-socrática para a socrática (cujo pensamento estava voltado ao homem e mais relacionado à virtude e ao conhecimento) e platônica (que difundiu a teoria das ideias e subsumiu o mundo imanente a uma ideia de mundo superior, transcendente, imutável e eterno), a filosofia rumou para o que Nietzsche chama de niilismo. Além dos escritos do próprio autor, apoiamo-nos também em alguns comentários sobre esse tema, dentre eles, os estudos sobre a filosofia de Nietzsche feitos por Scarlett Marton, a saber, Nietzsche: das forças cósmicas aos valores humanos ${ }^{3} \mathrm{e}$ Extravagâncias: ensaios sobre a filosofia de Nietzsche. ${ }^{4}$

Embora pareça contraditório que Nietzsche formule um imperativo ao mesmo tempo em que critica as abordagens cristã e metafísica que impõem determinações ao mundo, usamos o termo "imperativo" para designar seu eterno retorno como uma proposta de valorização da própria existência, sem atribuir valores superiores a instâncias que a dominem de fora. Este imperativo, diferente de um mandamento, por exemplo, ou do imperativo categórico kantiano, sugere ou aconselha que vivamos de modo que a única coisa que queiramos seja o retorno da mesma vida, sem submetê-la a uma lei moral exterior ou ao medo de um castigo. Nesse sentido, o imperativo existencial sugere centralizar na própria existência todos os esforços e atitudes do homem, de modo que sua

\footnotetext{
${ }^{3}$ Neste escrito a comentadora aborda o corpus nietzschiano a partir da questão do perspectivismo e da noção de valor. Dentre outros pontos, ela aborda a doutrina do eterno retorno como uma concepção fundamental do terceiro período do pensamento do filósofo e o traz a partir de duas leituras: a cosmológica e a qual ela denomina de ética. Cf. MARTON, S. Nota sobre o eterno retorno. In: Nietzsche: das forças cósmicas aos valores humanos, p.222.

${ }^{4}$ Este livro reúne um conjunto de artigos derivados dos vinte e cinco anos de estudos que a comentadora realizou sobre a filosofia de Nietzsche. Dentre os dez artigos, utilizaremos com mais assiduidade o artigo intitulado Eterno retorno do mesmo: tese cosmológica ou imperativo ético?, no qual a comentadora apresenta as duas possíveis leituras acerca da doutrina do eterno retorno, bem como as possíveis objeções e críticas feitas a ela.
} 
vida seja afirmada incondicionalmente e se torne o próprio critério de valor dessa afirmação.

Para chegarmos à doutrina como "a mais elevada forma de afirmação que se possa em absoluto alcançar" (NIETZSCHE, EH Assim Falou Zaratustra, p.79) veremos que pressupostos Nietzsche nos oferece para tanto. Num primeiro momento, trataremos do que chamamos tese cosmológica, isto é, sua interpretação de mundo como uma sucessão circular dos instantes encadeados no tempo. Para, na sequência, determo-nos em seu imperativo existencial, que parece ter um caráter exortativo, dado que sua hipótese cosmológica do retorno nos convida a ter um trato diferenciado com a própria vida a partir de sua repetição.

A princípio, sua argumentação gira em torno de uma formulação cósmica do retorno, presente, sobretudo, em vários fragmentos póstumos reunidos na obra $A$ Vontade de Poder. Sua perspectiva sobre o mundo consiste na identificação do tempo com um devir cíclico, desenvolvido a partir da repetição idêntica de todas as configurações cósmicas, isto é, as formas ordenadas nas quais o mundo se repete. A partir da consideração dessa hipótese da repetição, o filósofo dará ao homem o conselho de viver a mesma vida, infinitas vezes.

\section{A TESE COSMOLÓGICA}

A exposição de sua cosmovisão parte de três pressupostos básicos: (i) o mundo é constituído por grandezas determinadas de forças; (ii) essas forças são finitas (por isso, determinadas) e (iii) o tempo no qual o universo e as próprias forças se efetivam é infinito. Desse modo, da relação entre forças determinadas - um quantum sempre constante de forças que se efetiva e morre - e um tempo infinito surgiria a repetição destas forças, bem como suas mais diversas combinações para o preenchimento deste tempo infinito. E da repetição das forças deriva a repercussão dos acontecimentos e a circularidade deste movimento. Segundo Nietzsche:

Se o mundo pode ser pensado como grandeza determinada de força e como número determinado de centros de força [...] segue-se disso que ele há de perfazer um número de combinações computáveis no grande jogo de dados de sua existência. Em um tempo infinito, cada combinação possível haveria [...] de ser alcançada infinitas vezes. E então, entre cada "combinação" e seu 
"retorno", todas as combinações possíveis haveriam de ter decorrido (NIETZSCHE, Nachlass/FP Vol. IV 14[188] primavera de 1888).

Para Nietzsche, o mundo não é senão um conjunto de forças que se relacionam e agem entre si, não mais que uma "imensidão de força, sem começo, sem fim [...] como jogo de forças e ondas de força, ao mesmo tempo uno e vário, acumulando-se aqui e ao mesmo tempo diminuindo acolá" (NIETZSCHE, Nachlass/FP vol. III 38[12] junho-julho de 1885). A postulação de uma pluralidade é algo característico de seu pensamento: a força só existe no plural, não há uma força ( força em si), mas várias forças, que se efetivam na medida em que se relacionam com outras. Com efeito, as forças não são substâncias, mas um agir sobre, isto é, um efetivar-se.

O termo "força" é retirado por Nietzsche da física, contudo, não podemos afirmar que ele a utilizou no mesmo sentido que os físicos de sua época, mas a utilizou no sentido mais básico que temos do conceito, a saber, força enquanto aquilo que põe um corpo em movimento. Segundo o que Paolo D'Iorio nos explica, Nietzsche ficou a par da discussão da física da sua época e a partir daí parece ter formulado a hipótese cosmológica: havia um debate acirrado sobre a questão de se o mundo fora criado um dia e haverá um fim. Nessa discussão havia duas posturas, entre físicos e filósofos, em que se defendia, uns a morte térmica do universo, outros, a continuidade deste. Nietzsche se encontrava em meio aos que defendiam a segunda hipótese e que, a partir da postulação de que o mundo é contínuo, formulam uma tese que sustente sua continuidade, cujo principal argumento consistia em defender que em todo tempo decorrido até agora, ou então ele teria chegado ao fim do processo, o que é impossível, porque nesse caso o mundo já teria parado, ou ele estaria, necessariamente, fadado a repetir infinitas vezes ${ }^{5}$.

Poder-se-ia dizer que Nietzsche pensou o eterno retorno como um modo de justificar a durabilidade eterna do mundo, daí sua teoria das forças que explicam a relação de um tempo infinito com forças finitas (determinadas). ${ }^{6}$ A atividade da força consiste

\footnotetext{
${ }^{5}$ Cf. D’IORIO, 2006, p.79.

${ }^{6}$ Esta formulação de caráter científico surgiu da discussão que Nietzsche desenvolveu, sobretudo, inspirado nos escritos de Johannes Gustav Vogt, mais precisamente, com sua principal obra intitulada A força. Uma visão do mundo realista e monista (1878), mas Nietzsche não usa força no mesmo sentido que ele, pois, para Vogt, a força é "uma substância única, absolutamente homogênea, espacial e temporalmente infinita, imaterial e indestrutível" (cf. D’IORIO, p.70). Para Nietzsche, a força é o que há de mais fundamental para o mundo, embora corruptível e determinada, está em todo lugar e é o que constitui e move todas as coisas, inclusive o próprio homem (seus impulsos, desejos, expectativas e frustrações nada mais são do que forças que lhe são próprias).
} 
em agir sobre algumas e resistir a outras mais, numa dinâmica constante de se manifestar e se estender, exercer-se e tornar-se mais forte, a fim de atingir sua vontade de poder. A vontade de poder é entendida como a manifestação própria das forças em relação umas com as outras, seu caráter interno de crescimento que a orienta a se expandir para que não pereça. ${ }^{7}$ Em um fragmento póstumo de 1885, o filósofo nos fala que "este mundo é a vontade de poder e nada além disso!" (NIETZSCHE, Nachlass/FP vol. III 38[12] junhojulho de 1885. Ênfase de Nietzsche). Ele utiliza o termo "vontade de poder" (Wille zur Macht) como forma de expor ou falar a respeito da existência a partir da própria realidade efetiva.

Ao dizer que o mundo é vontade de poder e nada além disso, ele está propondo que o mundo (terreno, imanente) não é apenas um meio para um mundo melhor e superior (como o paraíso cristão) ou apenas a cópia de um mundo ideal. O mundo tem, em si mesmo, seu início, sua finalidade (que, a rigor, é exercer-se enquanto força e alcançar mais poder) e seu próprio fim, pois as forças morrem e se renovam no processo contínuo do tempo infinito. O mundo não é nada senão esta realidade. ${ }^{8}$ Apesar de a posteridade considerar o eterno retorno e a vontade de poder como uma metafísica ingênua por parte de Nietzsche, ele não parece ter tido tal propósito; podemos até pensar que por não poder ser demonstrado enquanto teoria científica, esta vontade pode ter um estatuto metafísico. No entanto, o que Nietzsche nos sugere é exatamente a negação de uma substância exterior que sustente o mundo, pois ele próprio enquanto força se sustenta. O mundo não é nada mais que um caótico conjunto de forças, energias, impulsos que agem e reagem para sobreviver e expandir. É nesse sentido que ele diz em certo momento "onde encontrei vida, ali encontrei vontade de poder" (NIETZSCHE, ZA, II, do superar a si mesmo, p.128), porque a vontade de poder é o exercício de atuação das forças que compõem e mantêm tudo o que vive, ou seja, parece ter um caráter orgânico. A força não é substancial, mas uma efetivação, da mesma forma que a vontade de poder também não é uma substância. O que Nietzsche adota com este termo não é A Vontade, presente, por exemplo, em Schopenhauer, mas o resultado das forças que se efetivam no mundo na medida em que lhes é possível. Logo, não existe A Vontade de poder, mas vontades de

\footnotetext{
${ }^{7}$ Cf. NIETZSCHE, Nachlass/FP Vol. III 36[31] junho-julho de 1885.

${ }^{8}$ Para uma explicitação maior de como Nietzsche concebe o mundo ver MARTON, S. A dança desenfreada da vida. In: Extravagâncias: ensaios sobre a filosofia de Nietzsche, 2009, p. 65-66.
} 
poder, na medida em que a luta entre forças se efetiva, pois é à medida que uma força esbarra em outras que o estímulo para se perpetuar enquanto força resistente aparece. E dessa luta não há télos, é apenas um conflito por mais poder, isto é, por sobrevivência e expansão das forças.

Embora múltiplas, as forças que constituem tudo que existe são finitas e se relacionam entre si de modo diferente possibilitando, assim, novas configurações de forças que agem em lugar das que se esvaem. ${ }^{9}$ Nesse sentido, a soma das forças é sempre constante, pois na medida em que algumas se dissipam, outras derivam da relação de anteriores. Contudo, o tempo no qual elas se efetivam é infinito. Disso, poder-se-ia concluir: ou o mundo atingiria um estado final devido à finitude das forças, ou os estados pelos quais ele passa hão de se repetir devido à infinidade do tempo e à necessária circularidade das somas de forças.

Ora, se o mundo "pudesse alcançar o estado de equilíbrio, ou se tivesse qualquer fim que encerrasse em si a duração, a imutabilidade, o uma-vez-por-todas" diz Nietzsche “então, este estado haveria de já ter sido alcançado" (NIETZSCHE Nachlass/FP vol. IV 14 [188] primavera de 1888) contudo, não alcançou. Nesse sentido, se assumirmos o pensamento de Nietzsche, onde as forças agem e se efetivam na medida em que encontram resistência e que é esta dinâmica que mantém o mundo, então não poderíamos aceitar que o mundo pudesse vir a alcançar um estado final (télos), dado que as forças morreriam e o próprio mundo sucumbiria. Na ausência das forças e de seu efetivar-se, o mundo deixaria de ser mundo. Mais ainda: um estado final é impossível devido ao caráter dinâmico das próprias forças. Sendo assim: "tudo vem a ser e eternamente retorna escafeder-se não é possível!". ${ }^{10}$ Este dinamismo que Nietzsche atribui às forças constituintes do mundo não deriva apenas de sua leitura e reflexão da problemática que permeava a física, parece resultar também de sua leitura da filosofia pré-socrática, sobretudo, de Heráclito, que via a arché do mundo no fluxo e na guerra entre os opostos.

\footnotetext{
${ }^{9}$ Em Assim Falou Zaratustra, na seção 'Dos três males', Nietzsche também diz que o mundo é finito, e que a sabedoria de Zaratustra consiste em escarnecer de todas as crenças em mundos infinitos. Cf. NIETZSCHE, ZA, III, dos três males, p.193.

${ }^{10}$ NIETZSCHE, Nachlass/FP Vol. III 24 [7] inverno de 1883. Ênfase do autor. Para mais elucidações a respeito da visão nietzschiana sobre a relação entre tempo e forças e sobre o modo como essa discussão serve como subsídio para sustentar uma tese cosmológica do eterno retorno, cf. NIETZSCHE Nachlass/FP 10[72] novembro de 1887- março de 1888; Nachlass/FP 11 [292] primavera-outono de 1881; Nachlass/FP [14] 188 primavera de 1888; Nachlass/FP 38[12] junho-julho de 1885. Ver também MARTON, 2009, p.6984.
} 
Em Ecce Homo Nietzsche deixa clara a influência que o pré-socrático exerceu em seu pensamento, diz inclusive que sua doutrina do eterno retorno poderia já ter sido formulada por ele. Devido a sua postulação do vir a ser e do movimento de opostos como princípio, o pré-socrático teria já subsídios para compreender sua doutrina da eterna repetição porque ele via o mundo tal como Nietzsche, isto é, um complexo de forças que se renovam e se consomem ( $C f$. NIETZSCHE, EH/O nascimento da tragédia, p.62). O resgate que Nietzsche faz do movimento postulado por Heráclito e atribuído às forças do mundo lhes confere um caráter dinâmico, de devir. Nesse sentido, as forças não podem deixar de se exercer, o seu querer-vir-a-ser-mais-forte as impediria de atingir uma condição estanque. O que nos leva a concluir que o mundo não é, mas vem-a-ser na medida em que as forças querem e alcançam cada vez mais poder. O que, mais uma vez, elimina a noção de télos, pois não se trata de determinar aquilo que o mundo deve ser ou $e ́$ a partir de uma única perspectiva (daí sua crítica às interpretações de caráter totalizante da religião e metafísica). Trata-se, ao contrário, de pensar aquilo que o mundo pode ser a partir de suas potencialidades, capacidades e possibilidades.

Com isso, percebemos que a intenção de Nietzsche parece ser propor uma concepção alternativa de mundo, oposta à linearidade em vigência na civilização ocidental. Com a teoria das forças, ele procura ilustrar o mundo por ele mesmo, sem fugir de sua própria esfera e recorrer a entidades transcendentes. As forças postuladas são inerentes ao mundo, são energias que o constituem e o mantêm. Nas palavras de Marton: "Ao conceber o mundo como totalidade permanentemente geradora e destruidora de si mesma, entende que não se acha submetido a um poder transcendente" (MARTON, 2009, p.108). Num mesmo sentido, a vontade de poder que, embora pareça ser um conceito metafísico, não remonta senão unicamente à manifestação que ocorre das forças constituintes do mundo. Este, então, é entendido como uma totalidade que gera e destrói a si mesma, vive de si mesma, "seus excrementos são o seu alimento" (NIETZSCHE, Nachlass/FP 14[188] primavera de 1888).

Com esta suposição de forças como o que constitui o mundo, Nietzsche se desvencilha das teses científicas que propõem um momento inicial e final para ele. As suposições religiosas, de um ser supremo que sustenta e ordena o universo (isto é, uma entidade exterior ao próprio mundo), estão fora de cogitação em seu pensamento. Bem como o mundo das ideias platônico e quaisquer outros conceitos metafísicos que, a seu 
ver, tão somente rotulam as forças plurais, como "sujeito", "substância", "substrato" - e qualquer outro que procure dar uma estabilidade que, segundo ele, é também exterior à dinâmica das forças do mundo. Se há alguma estabilidade ou se as forças coincidem e se mantêm numa unidade, isso ocorre devido à inter-relação da própria multiplicidade delas, nesse sentido, não há substância que as ordene, elas se ordenam por si mesmas. Com isso, o que ele pretende é nos mostrar que o mundo não necessita de um sistema exterior a ele, de substâncias ou entes exteriores que lhe deem sentido. As próprias forças têm seu próprio sentido, que consiste em manifestar-se e, tão somente, exercer sua vontade de poder.

Assim, vejamos que não é gratuita sua suposição cósmica, ela nos traz outras considerações pertinentes. A primeira é o caráter autônomo das forças do mundo em relação a qualquer coisa que a transcenda. A segunda é a crítica direta a ideais transcendentes que, para ele, não convém aplicar ao mundo, pois, desse modo, retirar-seia dele suas próprias forças. Assim, temos um primeiro pressuposto que nos levará à valorização da imanência, pois de que melhor maneira valorizar a vida senão partir da valorização do próprio mundo, enquanto o que possui um caráter imanente de poder?

Embora o que seja chamado de tese cosmológica faça parte do ensinamento do eterno retorno, ela é apenas $u m$ dos aspectos do que Nietzsche propõe. Conquanto ela esteja na forma de uma exposição teórica, o que interessa não é sua validade como explicação científica do tempo, mas seu impacto no âmbito humano. Não obstante Nietzsche estivesse sujeito a inúmeras críticas devido à incoerência lógica e matemática de sua doutrina, ${ }^{11}$ ele não estava preocupado em demonstrar o eterno retorno como uma teoria científica, pois não parecia ter pretensão de verdade.

A doutrina nietzschiana do eterno retorno não se limita a uma visão que procura descrever o princípio ou a continuidade do mundo. Nesse sentido, a apresentação do eterno retorno não se dá como uma fórmula dirigida ao entendimento, mas como um desafio, ou um conselho, direcionado à vontade, uma hipótese lançada a fim de questionar o homem, como um experimentalismo, o que é característico de seu pensamento. ${ }^{12}$ Assim,

\footnotetext{
${ }^{11}$ Acerca das possíveis críticas levantadas à doutrina do eterno retorno como uma teoria "cientificista" cf. MARTON, 2009, p.100.

${ }^{12}$ Nietzsche adota o experimentalismo como opção filosófica, o seu método oficial. "Ao colocar um problema em seus múltiplos aspectos, abordar uma questão a partir de vários ângulos, tratar de um tema adotando diversos pontos de vista, o filósofo está a fazer experimentos com o pensamento", afirma Scarlett 
há também o que chamamos aqui de imperativo existencial, que põe em questão o modo como o homem reagiria, e o que iria querer, frente à possibilidade de um retorno proposto como modo de ver o mundo. Partamos, portanto, para o domínio existencial do problema, que consiste no segundo momento da argumentação.

\section{O IMPERATIVO EXISTENCIAL}

Da explicitação de sua tese em nível cósmico, Nietzsche a transpõe para o nível humano. Um ponto importante na sua filosofia, relevante para o tema discutido, é a inseparabilidade entre homem e mundo; já destacada desde sua Gaia Ciência (1882) ao afirmar que não há nada de mais risível que colocar "homem" e "mundo" lado a lado, “separados pela sublime pretensão da palavrinha 'e’!” (NIETZSCHE GC V §346).

Porque, ao ver de Nietzsche, o homem e o mundo estão juntos apenas numa construção linguística. O termo "homem" é escrito ao lado do termo "mundo" e os dois permanecem juntos pela conjunção "e" sem que estejam juntos efetivamente, dado que enquanto o mundo é deixado de lado, o homem põe sua mente a pensar em outros mundos e ignora este no qual vive e pensa. Pretender juntar duas coisas que, de fato, estão separadas pela divagação do homem não passa senão de ironia. Além do que o fato da conjunção "e" precisar juntá-los denota que eles permanecem separados. Por isso, Nietzsche estende sua teoria das forças ao nível do homem e, dessa forma, o concebe também como um complexo de forças se efetivando e querendo se expandir para ganhar cada vez mais poder. Essa efetivação dinâmica é a instância biológica do homem, a qual não é mero invólucro que prende a alma ou uma máquina constituída por inúmeras partes. Antes ele é uma multiplicidade, composta de inúmeros "seres microscópicos" que agem, lutam, expandem-se e perecem constituindo os órgãos, as células e todas as atividades internas e externas; nesse sentido, cada órgão, cada célula, cada membro se expande e quer mais poder. ${ }^{13}$

Assim, Nietzsche nos mostra que o homem faz parte da mesma realidade que o mundo no qual ele se encontra, com uma mesma composição também regida por forças

Marton, "não é por acaso, aliás, que privilegia o estilo aforismático: se perseguir uma ideia é abandonar várias outras pelo caminho, o que é o aforismo senão a possibilidade de perseguir uma ideia partindo de diferentes perspectivas?" completa a comentadora, (MARTON, 2009, p.90-91).

${ }^{13}$ Sobre a concepção nietzschiana de corpo cf. MARTON, 1990, p.170-173. 
inerentes. O que reforça a negação, característica de seu pensamento, das dicotomias postuladas até então pela filosofia: como o homem e o mundo são constituídos por uma e mesma coisa e fazem parte da mesma realidade, elevar uma instância do homem acima das outras ou considerar uma realidade à parte mais importante que a efetiva deixa de ter sentido. $^{14}$

Desse modo, ele enfatiza a relação entre o homem e o mundo, não mais unidos por uma conjunção meramente linguística ou separados por particularidades que o homem pensa ter em relação a qualquer outro organismo, mas juntos num todo orgânico; não mais "homem $e$ mundo", mas "homem-mundo". O homem é parte integrante do jogo de forças que compõem e regem o universo; e suas ações estão submetidas a tais forças. Num mesmo sentido, como o homem age neste mundo do qual faz parte, em certa medida, ele também submete tais forças do mundo às suas ações, mas de modo diferente. Pois as forças do próprio mundo existem por si, não necessitam da ação humana, enquanto as ações não se efetivam sem a interferência das forças do universo. Portanto, ainda que o homem possa submeter as forças às suas ações, é somente na medida em que age, ou seja, é apenas no instante da ação.

Seria questionável se no eterno retorno não se subentende certo determinismo, dado que o homem está determinado pelas forças que regem e mantêm o universo. Contudo, isso ressalta o caráter da relação que o homem mantém com o mundo - este suposto determinismo demonstra que o homem tem a possibilidade de agir, devido seus impulsos e afetos (o que não deixam de ser forças inerentes), mas tal possibilidade só pode ser atualizada no mundo no qual o homem se encontra. Daí a inseparabilidade do homem com o mundo, ele não está preso e determinado a fazer algo de modo que alcance um télos, mas deve se reconhecer enquanto parte de um mundo no qual pode agir e pelo qual será afetado, pois não é de modo algum alheio a ele. Nas palavras de Marton (2009, p.118. Ênfase nossa): "Destronado, o homem deixa de ser um sujeito frente à realidade para tornar-se parte do mundo". A ação humana e a efetivação das forças, dessa forma,

\footnotetext{
${ }^{14}$ Aqui, trata-se de uma crítica direta à tradição, tanto da filosofia quanto da cultura num sentido mais amplo. A começar em Platão e sua teoria das ideias, depois Descartes e sua reflexão acerca da maior facilidade em conhecer o espírito que o corpo e a superficialidade com que ele descreve o próprio corpo, em seguida, podemos até citar a religião que abomina e torna pecaminoso tudo que é corpóreo e mundano. Por fim, Kant e sua moral deontológica que institui a ação fundamentada em regras morais formuladas pela razão, que prevalece em detrimento do desejo. Cf. NIETZSCHE, F. A Vontade de Poder como conhecimento. In: A Vontade de Poder, 2008a, p.255-316.
} 
justapõem-se, dado que, do mesmo modo que as forças possibilitam a ação humana, esta repercute no mundo e, consequentemente, implica em mais forças que dão continuidade ao grande jogo de dados da existência numa grande cadeia.

Ora, se o homem interfere, da maneira como age, nas forças constituintes de sua realidade e se estas forças possibilitam a repetição dos momentos efetivados, então poderíamos afirmar que a ação humana também interfere no eterno retorno, na medida em que ela efetiva suas forças neste mundo que retornará. Logo, esta nova cosmovisão possibilita ao homem um grau maior de participação que abordagens religiosas ou metafísicas, onde o homem desenvolve um papel meramente contemplativo ou devoto, por exemplo. Nesse sentido, o homem também participa do processo de repetição na medida em que age no instante, pois é exatamente neste em que o homem se insere como força atuante e determinante daquilo que retorna - eis onde se encontra o caráter existencial da sua doutrina.

Considerar o instante como fio condutor do que se repete remonta o compromisso direto que o homem tem com as configurações que hão de retornar. É precisamente o instante que posiciona o homem como parte do retorno e o momento propriamente dito em que o homem se dá conta deste. Desconsiderá-lo seria restringir a doutrina à primeira tese, isto é, a cosmológica, assim ela não seria mais que um apático retornar enfadonho desprovido de sentido. O problema de restringir a doutrina à primeira tese e considerá-la um retorno sem sentido de todas as coisas é que dessa forma cairíamos no niilismo, e isso é exatamente o que Nietzsche quer evitar com o aspecto existencial da doutrina. Ele nos alerta que tal pensamento pode nos aniquilar ou nos regozijar, tudo depende do modo como vivemos e como agimos. Daí a importância de seu imperativo existencial, pois ele exorta o homem a ter um trato diferente com a vida, de modo que deseje o retorno idêntico dela e não a veja de maneira niilista, sem sentido e valor intrínsecos a partir deste retorno. $^{15}$

O caráter existencial está precisamente no ponto de considerar a ação humana como decisiva daquilo que retorna. Desse modo, o homem não se submete a uma repetição sem sua interferência, pois ele também age, exercer-se, atua, busca mais poder. Em suma, como ele é parte do mundo, não só retorna junto com tudo, como também pode

\footnotetext{
${ }^{15}$ Cf. MARTON, 2009, p. 85-118.
} 
definir aquilo que retornará na medida em que agir. Com isso, a doutrina teria o papel de dar ao homem a possibilidade de pensar sobre sua condição existencial mediante a consideração de que se aquilo que está vivendo é aquilo que deseja que retorne. Com efeito, o caráter do eterno retorno é instaurado pelo impacto existencial causado no homem quando este se depara com a possibilidade do retorno eterno de uma mesma e idêntica vida.

É em sua A Gaia Ciência (1882) que Nietzsche nos apresenta sua doutrina como um desafio através da boca de um demônio, sua questão é:

\begin{abstract}
Se um dia ou uma noite, um demônio se espreitasse em tua mais solitária solidão e te dissesse: "Esta vida, assim como tu a vives e como a viveste, terás de vivê-la ainda uma vez e ainda inúmeras vezes; e não haverá nela nada de novo, cada dor e cada prazer e cada pensamento e suspiro e tudo o que há de indizivelmente pequeno e de grande em tua vida há de te retornar, e tudo na mesma ordem e sequência [...] A eterna ampulheta da existência será sempre virada outra vez - e tu com ela, poeirinha da poeira!" (NIETZSCHE, GC IV, $\S 341$. Ênfase nossa).
\end{abstract}

O que Nietzsche nos lança como possibilidade é o retorno eterno de uma mesma e idêntica vida. Ele é incisivo: o que há de maior e menor, as maiores alegrias e as mais ínfimas dores, tudo retornará, não de modo melhor ou pior, mas de modo idêntico. Nesse sentido, o homem está fadado a viver, pela eternidade, tudo o que concretiza. Assim, embora o homem ainda possa determinar o que pode ou não retornar na sua vida, ele não pode impedir que retorne aquilo que já realizou, portanto, seu fado é construído por ele mesmo - construído na medida em que escolhe tal ou tal coisa e age de tal ou tal forma. Por isso, o ponto principal do aspecto existencial diz respeito à $a c ̧ a \tilde{o}$ : o modo como o homem age no instante, determina o modo como será esse mesmo instante por toda a eternidade.

Contudo, sua formulação se apresenta de modo condicional ("Se um dia ou uma noite"), logo, a repetição é dada como hipótese a ser pensada, experimentada, o que ressalta o fato de que Nietzsche não tinha a intenção de prová-la e a formula como provocação. À apresentação do eterno retorno como a repetição de todas as coisas vividas ainda se segue a questão: "Não te lançarias ao chão e rangerias os dentes e amaldiçoarias o demônio que te falasse assim? Ou viveste alguma vez um instante descomunal, em que lhe responderias: 'Tu és um deus, e nunca ouvi nada mais divino!'” . O que importa aqui 
é: qual seria a reação do homem para com a vida, se ele soubesse que ela vai repetir, se qualquer ação efetivada uma vez estivesse fadada a se repetir idêntica e eternamente? Vejamos que para tal reflexão há duas possíveis respostas: ou este pensamento nos destruiria, porque certamente não quereríamos que fosse real, ou nos alegraríamos em último grau, dado nossa forma de viver e agir.

Para que tal pensamento não faça o homem ranger os dentes e odiar este demônio e a própria vida, é preciso que ele a ame, alegre-se frente a ela e a assuma como sua forma de agir no mundo. Não vê-la como meio para um paraíso ou um mundo superior, mas com o valor mais elevado impresso em si mesma, tal como ela é. Por isso, a pergunta "queres isso ainda uma vez e um número infinito de vezes?" seria o "mais pesado dos pesos" sobre todas as ações do homem, pois seu único compromisso seria se conscientizar de que sua ação no instante poderia repercutir por toda a eternidade na qual ele retornaria. A partir disso, ele precisaria ter a certeza de que o que ele está prestes a realizar é exatamente o que ele quer.

Desfaz-se o compromisso com um télos e se assume um compromisso com a existência. Não mais controlado ou avaliado por um deus onisciente, não mais determinado por um finalismo metafísico-teleológico, mas unicamente comprometido com o ciclo condicionado por forças, do qual ele mesmo faz parte. Não mais "estar à espera de alegrias, bênçãos nem perdões desconhecidos e distantes, mas viver de tal modo que queiramos viver outra vez e queiramos viver eternamente desse modo! - Em todo momento nos vemos frente a nossa tarefa" (NIETZSCHE KGWB 11[161], M III 1 Primavera - outono de 1881).

O modo como Nietzsche nos apresenta a doutrina remonta sua proposta de afirmação da existência. Entre a crítica à metafísica (a negação de outro mundo) e o desafio do demônio (que faríamos frente à possibilidade do retorno da mesma vida), ele nos propõe que o homem não possui outra vida além desta e, posto que é responsável pelo que vive nela, é imprescindível que a afirme.

Novamente, segundo Marton (2009, p.115):

Em vez de esperar que um poder transcendente justifique o mundo, o homem tem de dar sentido à própria vida; em vez de aguardar que venham redimi-lo, deve amar cada instante como ele é. E não há afirmação maior da existência que a afirmação de que tudo retorna sem cessar. 
Sem Deus, o homem precisa decidir de que modo viver sua vida e que ações tomar, sem determinação a não ser a resultante de seu próprio agir, o homem se vê sozinho. Assim, as ações do homem não se guiariam por uma vã esperança de redenção no além, nem pelo medo do castigo eterno no inferno, mas pelo "peso" da eternidade, não mais localizada num além-mundo, mas neste mundo. Logo, sua doutrina aproxima o homem da terra, solo próprio onde ele atua e da própria vida - esta se torna o seu mais alto valor. ${ }^{16}$ O que nos leva à noção nietzschiana de amor fati, isto é, o amor que o homem precisa ter para com o seu destino, que é o seu único fado, que por sinal é construído por ele mesmo na medida em que efetiva no mundo suas forças. Em Ecce homo (1888), ele nos apresenta sua fórmula deste amor necessário para conceber a afirmação incondicional da existência:

\begin{abstract}
Minha fórmula para a grandeza no homem é amor fati: nada querer diferente, seja para trás, seja para frente, seja em toda a eternidade. Não apenas suportar o necessário, menos ainda ocultá-lo - todo idealismo é mendacidade ante o necessário - mas amá-lo... (NIETZSCHE, EH II 10).
\end{abstract}

O amor fati é o critério essencial para a afirmação do eterno retorno, ambas as concepções andam juntas, pois quem afirma o eterno retorno, afirma-o porque ama seu destino (não um destino teleológico, mas o qual ele mesmo cria a partir de seu agir). Logo, o amor fati se apresenta como um pressuposto da doutrina: para a concepção do eterno retorno não basta que o homem suporte o necessário, dissimule-o ou o negue, é preciso amá-lo, pois faz parte de si mesmo. O indivíduo que ama a vida tal como é, é uma espécie distinta de homem, nobre, que cria valores a partir de suas próprias vivências e vive a partir de seus próprios valores. Contudo, tal espécie de super-homem não se distingue pela condição social ou política, parece ser algo mais particular ${ }^{17}$. Trata-se de um criador dos valores que regerão sua vida ${ }^{18}$, o homem que cria e afirma suas forças e

\footnotetext{
${ }^{16}$ Neste sentido, Nietzsche diz pela boca de Zaratustra: "Eu vos rogo, meus irmãos, permanecei fiéis à terra e não acrediteis nos que vos falam de esperanças ultraterrenas" (NIETZSCHE, ZA Prólogo de Zaratustra, p.30).

${ }^{17}$ Cf. MARTON, 2009, p. 116.

${ }^{18}$ Essa discussão pode ser mais bem compreendida com a leitura de Genealogia da Moral (1887). Nietzsche investiga a emergência dos valores, perguntando-se pela verdadeira origem de nosso bem e nosso mal, constata que a moral ocidental possui duas vertentes: a moral nobre e a escrava. Ambas possuem valores como bem e mal (no caso da escrava), ou bom e ruim (no caso da nobre). O que as difere é o modo como emergem enquanto princípio de valoração. A moral nobre parte do valor bom que atribui a si mesma, tudo que é útil, feliz, fértil, vívido, afirmador. Nesse sentido, tudo o que afirma as próprias potencialidades inerentes é bom e faz parte da moral nobre. Já a moral escrava submete-se à valoração já criada pela moral 
tem sua própria valoração é forte, este afirma a existência e, por conseguinte, o retorno dela.

Na relação entre o homem e o mundo, não há espaço para forças exteriores transcendentes - o homem está sozinho num mundo e é preciso que ele o reconheça como seu lugar de atuação e de efetivação de suas próprias capacidades. Nesta realidade em que o homem existe, há somente forças exteriores contingentes (do mundo) e forças interiores (do homem), as quais ele precisa saber conciliar com as forças exteriores. Mais precisamente, o homem é repleto de impulsos, desejos, expectativas e frustrações - forças que agem e procuram se exercer num mundo que também é repleto de forças, que muitas vezes são discrepantes com as forças do homem. Saber se superar e lidar tanto com as forças exteriores, e, sobretudo, com as interiores, é afirmar a vida em sua plenitude. É conferir um sentido imanente a ela afirmando cada uma de suas partes, em quaisquer de seus aspectos e ser forte em sentido nietzschiano.

Com isso, a doutrina do eterno retorno se nos mostra como a proposta da valorização da existência, procura levar o homem a conferir um sentido imanente a ela afirmando-a plenamente e criando seus próprios valores que a orientarão. Para tanto, Nietzsche estabelece o critério de "querer um número infinito de vezes". De uma pergunta, esta sentença se torna um imperativo; isto é, um conselho de modo que o retorno eterno da mesma vida seja motivo de regozijo e não de desespero. Em um fragmento que seria publicado postumamente, Nietzsche propõe:

Minha doutrina diz: viver de tal modo que tenhas que desejar viver de novo, essa é a tarefa - pois o fará em qualquer caso! - Aquele para quem o esforço seja o sentimento supremo, que se esforce: aquele a quem o repouso seja o sentimento supremo, que repouse; aquele para quem subordinar-se, cumprir, obedecer seja o sentimento supremo, que obedeça. Espero que se dê conta daquilo que é para ele o sentimento supremo e não evite meios! Nisso se vai a eternidade! (NIETZSCHE, FP Primavera-Outono de 1881, 11[163]).

nobre e apenas inverte os valores de bem e mal. Logo, nesta moral, tudo que é feliz, afirmador, fértil, útil é mal, e ao valor bem cabe tudo que lhe é oposto, isto é, aquilo que é submisso, nocivo, doente, débil, comum, infeliz, fraco, inútil. A moral escrava parte de uma inversão da moral nobre, esta cria a si mesma como um "triunfante Sim" às suas forças. A moral nobre é atribuída, por Nietzsche, sobretudo, aos gregos antigos, pois não há nada de mais afirmador que enfrentar a guerra, cultuar o corpo e morrer com honra. Já a moral escrava é um atributo, sobretudo, da religião judaico-cristã, que nega este mundo, torna o corpo um símbolo de pecado e cria o consolo de que haverá outro mundo melhor após a morte. Logo, quando Nietzsche se refere ao homem superior, forte, refere-se àquele que afirma suas forças e cria valores a partir de suas próprias vivências e que não se submete a valores morais previamente instituídos exteriormente. 
A rigor, se considerarmos a organicidade do pensamento sugerido por Nietzsche, isto é: (i) a hipótese de uma concepção cíclica do tempo, no qual tudo que é realizado no instante se repetirá por toda a eternidade. A partir do que, (ii) elimina-se entidades transcendentes que sustentem o mundo; (iii) tornando-se, assim, próprio do homem a realização das próprias forças, na medida em que ele se reconhece como parte indissociável da realidade efetiva. Então, podemos assumir que cabe unicamente ao homem decidir e realizar aquilo que ele gostaria que retornasse eternamente, pois ele retornará em todo caso. O que remete ao que já comentamos acerca da possibilidade do homem de interferir no retorno e, ao mesmo tempo, da imprescindibilidade deste, isto é, o retorno não pode ser impedido, apenas configurado pelo homem à medida que ele age.

Ao agir, o homem estará realizando o que lhe causa o mais alto sentimento e, assim, estará afirmando a eternidade, pois o que retornará na sua vida será o que ele concretizou, enquanto objeto de seu mais alto sentimento, no instante. Nesse sentido, o eterno retorno, mais que uma tese determinista que impõe a repetição incessante e necessária de todas as coisas, propõe a valorização incondicional da vida a partir dessa mesma repetição tomada como hipótese. A perspectiva nietzschiana de uma circularidade temporal remete à consciência que o homem precisa ter do peso inerente a cada ação efetivada dentro desta suposta circularidade. Desse modo, a doutrina não seria apenas a constatação de que o mundo simplesmente escoa num tempo infinito, mas teria o papel de enfatizar o valor intrínseco que a própria existência (e as ações do homem) carrega. A partir do que, ressalta a necessidade de o homem reconhecer tal valor, antes até: criá-lo a partir de suas ações e deixar de subsumir a existência a valores que pairam acima de suas próprias experiências e vivências.

\section{CONSIDERAÇÕES FINAIS}

Com o intuito de refletir acerca da reação do homem frente à existência, tal como ela é vivida pelo próprio homem, Nietzsche formula e nos apresenta o eterno retorno do mesmo como a hipótese de um tempo cíclico, no qual tudo retorna à medida que é constituído por forças finitas em efetivação e sobreposição. Tentamos nesse trabalho expor tal doutrina como um imperativo que sugere a valorização da existência como um todo a partir da consideração de que o que é concretizado pode repercutir por toda a 
eternidade. As considerações feitas nesse artigo versaram sobre as duas possíveis abordagens do eterno retorno e procuraram enfatizar o segundo aspecto, isto é, o existencial, como o caráter próprio deste pensamento, através do qual Nietzsche procura pôr em questão o modo como o homem reage frente à existência.

A primeira abordagem se apresenta como uma tese cosmológica, isto é, a perspectiva nietzschiana acerca da constituição e efetivação do mundo através da relação entre um tempo infinito e forças finitas que surgem, efetivam-se e se esvaem. A partir desta consideração, pode-se pensar que o mundo viria a se repetir dado o número finito de possibilidades de sua efetivação devido à finitude das forças em relação com um tempo infinito. Disto conclui-se que, para o filósofo, o mundo não é, no sentido de um substrato imutável e essencial, mas vem-a-ser, no sentido de que se torna e se concretiza na medida em que as forças se efetivam nele. Com isso, recusa-se a suposição metafísica de uma essência imutável e eterna e a consideração de que o mundo físico (enquanto efetividade) não possui um valor intrínseco. Além do que, com o reconhecimento das forças intrínsecas ao mundo, Nietzsche parte da valorização deste mundo tal como vem a ser para propor a repetição da existência nele.

A segunda é o que denominamos aqui de imperativo existencial enquanto o conselho dado por Nietzsche a partir da possibilidade lançada de que o mundo pode vir a retornar. Ora, diz-nos o filósofo, se o mundo há de retornar, e nós com ele; se podemos agir e, assim, configurar os modos pelos quais o mundo há de se repetir, então, que vivamos de modo tal que nos seja gratificante este retorno, isto é, de modo que a repetição de nossa própria vida seja motivo de regozijo e não de desespero. Resgatando a questão do demônio, se parássemos para pensar na hipótese do retorno, será que já vivemos um momento de modo pleno a ponto de querermos que toda a existência repercuta tal como a vivemos? Assim, viver um momento de modo e querer a repetição dele implica querer a repetição de todos os momentos, uma vez que todos fazem parte de nossa existência. ${ }^{19}$ A suposição da repetição não se torna a constatação de um retornar vazio, mas um modo de significar a existência a partir dela mesma, antes até: a partir de sua repetição.

Em suma, a reflexão feita por Nietzsche a respeito da existência a partir da concepção de temporalidade traz à tona um confronto (típico de seu pensamento) à toda

\footnotetext{
${ }^{19}$ Cf. NIETZSCHE Nachlass/FP 7[38] final de 1886-primavera de 1887: "se dissermos sim em um único instante, então teremos dito sim não só a nós mesmos, mas à existência como um todo”. 
uma tradição ocidental que, ao seu ver, impunha à vida valores que a regiam de fora. Com a proposta de uma valorização do mundo, que é inseparável do homem, e que alcança o máximo de seu poder a partir do exercício de todas as suas forças constituintes, o filósofo procurou trazer para a própria terra o seu valor e um significado, que não lhe é imposto, mas engendrado por suas próprias forças. Como o homem faz parte destas forças constituintes do mundo, isso dá um caráter mais de ator que de espectador ao homem, pois ele é também capaz de agir e interferir em seu destino. Nesse sentido, embora pareça ser um mero determinismo o que está sendo proposto em sua tese cosmológica, se pensado por um viés existencial, Nietzsche está a ressaltar o caráter atuante e determinante do homem que precisa ser capaz de ter para si bem claro o que ele deseja viver e que o valor da vida é atribuído a ela a partir de suas vivências. Logo, a própria existência do homem no mundo e o modo como ele reage frente a ela definem o valor que lhe cabe.

\section{REFERÊNCIAS BIBLIOGRÁFICAS}

ARALDI, C. Niilismo, criação, aniquilamento: Nietzsche e a filosofia dos extremos. São Paulo: Discurso Editorial, 2004.

CALOMENI, T. C. B. A Redenção da temporalidade: A Trágica intuição do eterno retorno em Nietzsche. In: Cadernos Nietzsche. São Paulo, nº 18, p.93-109, 2005.

D'IORIO, P. O eterno retorno. Gênese e interpretação. In: Cadernos Nietzsche, São Paulo, no 20, p.69-114, 2006.

MARTON, S. A Morte de Deus e a Transvaloração dos Valores. In: HYPNOS. São Paulo, ano 4, n. 5, p.133-143. $2^{\circ}$ semestre, 1999.

Eterno retorno do mesmo: tese cosmológica ou imperativo ético? In: MARTON, S. Extravagâncias: ensaios sobre a filosofia de Nietzsche $-3^{\text {a }}$ ed. - São Paulo: Discurso Editorial e Editora Barcarolla, 2009.

brasiliense, 1990.

MÜLLER-LAUTER, W. A doutrina da vontade de poder em Nietzsche. São Paulo: ANNABLUME, 1997.

NIETZSCHE, F. W. A Gaia Ciência. Tradução Paulo César de Souza. São Paulo: Companhias das Letras, 2012. 
Assim Falou Zaratustra: Um livro para todos e para ninguém. Tradução de Mário da Silva. 9a edição. Rio de Janeiro: Bertrand Brasil, 1998.

. Ecce homo. São Paulo: Companhia das Letras, 2008 b. 2008 .

Fragmentos Póstumos. Volumen II (1875-1882). Madrid: Editorial Tecnos, 2010 .

Fragmentos Póstumos. Volumen III (1882-1885). Madrid: Editorial Tecnos, 2006.

Fragmentos Póstumos. Volumen IV (1885-1889). Madrid: Editorial Tecnos,

STAMBAUGH, J. The Problem of Time in Nietzsche. London and Toronto: Associated University Press, 1987. 